$\checkmark$ of years ago provided opportunities for the evolution of grasses, horses and camels, all of which have been indispensable to humans. On a shorter timescale, the primacy of wood exploitation (where timber was available or could be traded for) gave way to the ages of bronze and then iron, as technology evolved to take advantage of copper and tin and to forge steel. Trade developed on both sea and land, and its corollaries ranged from cultural exchange to wars, all conditioned by geography and climate.

Such a grand sweep of history and prehistory could be chaotic, but Dartnell's story is beautifully written and organized. His infectious curiosity and enthusiasm tug the reader from page to page, synthesizing geology, oceanography, climatology, meteorology, ge o graphy, palaeontology, archaeology and political history in a manner that recalls Jared Diamond's clas-

"Only an
acquaintance
with Earth
science allows
people to
understand the
risk in where
they build their
houses."
sic 1997 book

Guns, Germs, and Steel. Ever surprising, Dartnell juxtaposes facts as different as the sources of stone for the pyramids and the natural geographic divisions that separate Eastern Orthodox, Roman Catholic and Protestant Christianity.

This engaging treatment holds a larger lesson. In public education, the planetary sciences (geology, geography, climatology and astronomy) usually take a back seat to the more reductionist aspects of chemistry, physics and biology - at least in the United States. Here, 'rocks for jocks' - Earth science - is often taught by the football coach, and populated by students who, it is thought, 'can't handle' the other sciences. All the sciences are important. But only an acquaintance with Earth science allows people to understand whether there is a risk in building their houses on the Russian River floodplain in California or an eroding cliff in Goa, India; how the sediment under a house might withstand a magnitude-8.0 earthquake; whether the aquifers in a valley's hills are sufficient to sustain a golf course; and whether its soils can support plant communities that won't turn into a fatal tinderbox during dry years of a climatic cycle. In our current geopolitical climate, this knowledge is more important than ever.

Kevin Padian is in the Department of Integrative Biology and the Museum of Paleontology of the University of California, Berkeley.

e-mail:kpadian@berkeley.edu

\section{The non-stop waste of water}

\section{Margaret Catley-Carlson reflects on millennia of resource mismanagement.}

$\mathrm{E}$ very year, water shortages affect more than one-third of the world's population. In 2017, even Rome - ancient pioneer of urban water provision - saw its myriad public drinking fountains switched off. Environmental economist Edward Barbier plunges deep into these and other stories from the fascinating, often fraught world of water management past and present in his scholarly but accessible study The Water Paradox. Barbier investigates, too, the threats looming over water resources.

The paradox is this: despite ample scientific evidence on exploitation and overuse of fresh water, and ample wealth, knowledge and institutional power, humanity has created a preventable water crisis. We persist in exploiting fresh water as if it were abundant, even as we recognize its scarcity. By 2040, 2 billion people will be affected by the global groundwater crisis (more water being withdrawn than is refilling aquifers); Indonesia, Iran and South Africa will be among the countries suffering from high or extreme water stress.

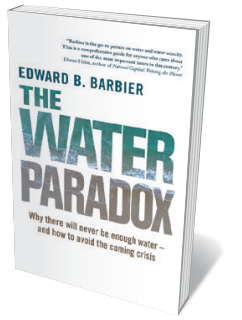

The Water

Paradox:

Overcoming

the Global

Crisis in Water

Management

EDWARD B. BARBIER

Yale University Press (2019)
The pressure will be environmental and agricultural, and will intensify social and economic crises.

If a good slice of our world falls apart because we cannot implement change, it will not be because we lacked historical warnings. Societies, city states and regions have collapsed into rubble or dry leaves because of environmental mismanagement. It could happen again.

To understand how, Barbier delves into millennia of misuse. He surveys irrigation and agricultural practices in the ancient Middle East, China, Europe and beyond, citing the 'hydraulic hypothesis' of early-twentieth-century historian

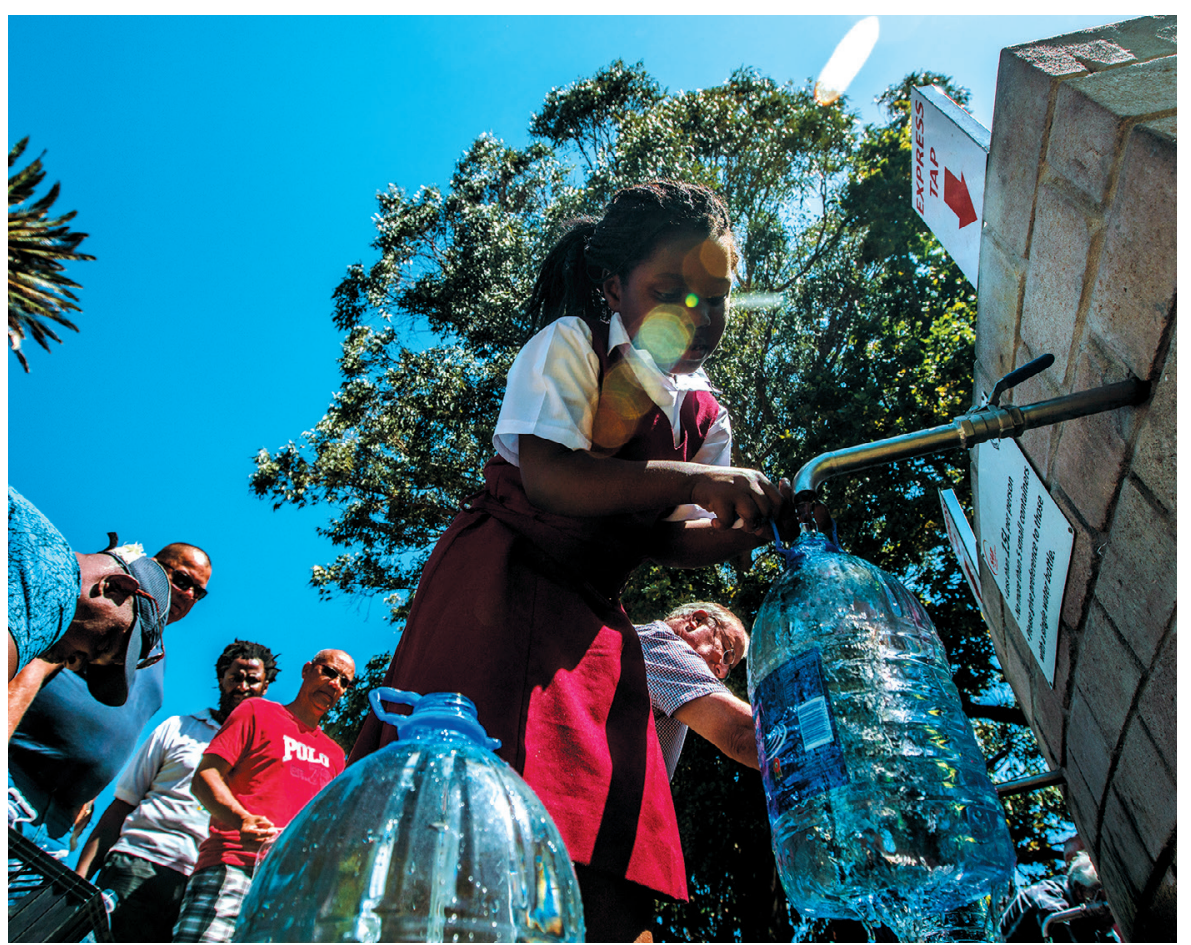

Residents of Cape Town, South Africa, queue to refill bottles during a 2018 water shortage. 
Karl Wittfogel (P. Ball Nature 564, 186-188; 2018). This held that early agriculture-based empires such as Sumer in Mesopotamia rose through control of water, but tended to squander it - leaving them vulnerable to environmental degradation and outside attack.

More recent examples include the 'land rushes' that gripped Australia, New Zealand, South Africa and North America from 1650 to 1900 . Barbier points out that these vast expansions of frontiers and economic gain were hugely dependent on claiming 'free' water. That practice lingers. Markets generally undervalue lakes, waterways and aquifers that are public goods. One impact of that, he notes, is a "use it or lose it" attitude, encouraging territoriality and, ultimately, water wars.

Barbier calls for an end to policy, markets and governance that underprice water and allow it to be used as if it were plentiful. Our innovations, he argues, are generally geared to expanding not reducing consumption.

He makes his points eloquently, offering a wellspring of facts and figures. I am impressed by the dozens of scholarly lists, tables and compendia, on history, current problems or tools for finding solutions to, for instance, types of water market that bring both benefits and perils. Those include river basins at risk from future conflicts; groundwater depletion now and in the near future; water grabbers and the grabbed-from; and many more.

But the book has three key gaps.

First, Barbier is so clear and thorough that I really hoped he would take on the paradox itself: our apparent inability to avert a

human-driven existential threat. I hunted for a glimmer of a way forward, an untilnow hidden path out of our political paralysis, or a psychological glitch that could be redirected. I searched for philosophers or social psychologists who could suggest ways of waking a sleeping world as the waters rise and fall. But on this key point, Barbier is silent.

Second, he almost entirely omits ongoing public opposition to most of his proposed measures - such as tackling the chronic underpricing of water - that is fuelled by factors such as aversion to taxes.

\section{"Markets generally undervalue} lakes, waterways and aquifers that are public goods."

Substantial hikes in

water prices, water markets and governance involving greater private-sector dominance are anathema to many (M. Catley-Carlson Nature 505, 288-289; 2014).

Large companies and other players were chased out of water-asset management in the 2000 s, criticized by a number of non-governmental organizations, the political left and unions. That grass-roots movement is part of a larger tide of resistance to globalization and multinational companies. It has affected the availability of investment capital, the direction of World Bank lending and significant strands of public opinion. Thus, in effect if not intent, Barbier prescribes an approach that is almost certain to lead to discord, making it problematic for governments. Also missing from his discussion are some of the less-than-wise corporate steps that have triggered successful protest.

Third, Barbier ignores the very real tension between some of his sensible suggestions and many countries' lack of economic, infrastructural and governmental capacity to implement them. He acknowledges the mismatch between water governance and institutions and our needs. If this is to be a book for the world, that obstacle course needs more attention (perhaps even a list of on-the-ground prerequisites for reform). And, although he covers desalination well, many other kinds of processing barely get a look-in: water reuse, waste-water reprocessing and the extraction of resources from industrial and domestic waste waters.

The Water Paradox is, however, jargon-free and readable, brilliantly detailing both problems and remedies. I hark back to Barbier's words on the fountains of Rome. To learn that 2017 was the first time in 2,000 years that these hydro-engineering marvels were turned off in response to drought provokes tears of sorrow and frustration. We know that it is happening. We do not act. That is the paradox.

Margaret Catley-Carlson has chaired the Global Water Partnership, the World Economic Forum's Global Agenda Council on Water and the Suez Foresight Advisory Council, and was a member of the UN Secretary-General's Advisory Board on Water and Sanitation, among others.

e-mail:m.catley-carlson@cgiar.org

\section{Life versus entropy}

\section{Timo Hannay explores a study of life that takes up where Erwin Schrödinger left off.}

$\mathrm{B}$ iology, long the domain of qualitative theories and experimental subjects that refuse to do the same thing twice, is now thoroughly data-driven. Propelled by the twentieth-century revolutions in molecular biology and computing, its emphasis has shifted from observing and describing to sequencing and calculating. In the process, biology has increasingly become like physics - a development that has caught the attention of quite a few physicists.

One such boundary-transcending thinker is the cosmologist and writer Paul Davies. His latest book, The Demon in the Machine, presents a case that information is central not just to doing biology, but to understanding life itself. He follows in esteemed footsteps. In 1943, the Austrian physicist Erwin

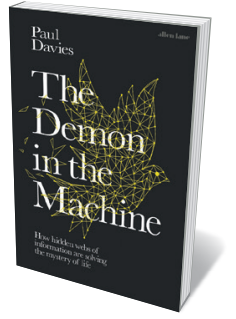

The Demon in the Machine: How Hidden Webs of Information Are Finally Solving the Mystery of Life PAUL DAVIES Allen Lane (2019)

Schrödinger delivered a landmark series of public lectures at Trinity College Dublin. Published the following year as What Is Life?, it explained many principles of molecular genetics - a decade before the structure of DNA was discovered (see P. Ball Nature 560, 548-550; 2018).

As a quantum theorist, Schrödinger was particularly struck by the observation that atoms, although profoundly unpredictable, can form highly ordered systems. Furthermore, those systems persist for long periods and even replicate, thus seeming to evade the second law of thermodynamics, which states that total entropy, or disorder, can only increase.

This classic account serves as Davies's starting point. As a cosmologist, however, his principal question arises from a consideration not of the irreducibly small, but of the incomparably large. If life exists elsewhere in the Universe, Davies wonders, how can we recognize it? Searches for signs of liquid water, organic chemistry or certain atmospheric gases (such as oxygen, carbon dioxide or methane) make sense given the 